\title{
Clinical Value of Human Leucocyte Antigen G (HLA-G) Expression in the Prognosis of Colorectal Cancer
}

\author{
Roghaieh Samadi, ${ }^{1}$ Ehsan Nazemalhosseini Mojarad, ${ }^{2}$ Mahsa Molaei, ${ }^{2}$ Faranak Kazerouni, ${ }^{1}$ Hamid \\ Asadzadeh Aghdaei, ${ }^{2}$ Masoumeh Navidinia, ${ }^{1}$ and Ali Rahimipour ${ }^{1,}$ \\ ${ }^{1}$ Department of Medical Laboratory Technology, School of Allied Medical Sciences, Shahid Beheshti University of Medical Sciences, Tehran, IR Iran \\ ${ }^{2}$ Gastroenterology and Liver Diseases Research Center, Research Institute of Gastroenterology and Liver Diseases, Shahid Beheshti University of Medical Sciences, Tehran, IR \\ Iran \\ "Corresponding author: Ali Rahimipour, School of Allied Medical Sciences, Shahid Beheshti University of Medical Sciences, Tehran, IR Iran. Tel/Fax: +98-2126850560; \\ +98-9126904482, E-mail: rahimipour.ali95@gmail.com
}

Received 2016 October 14; Revised 2016 December 03; Accepted 2017 April 03.

\begin{abstract}
Objectives: Overexpression of human leukocyte antigen G (HLA-G) in several malignant tumors has been reported. The aim of our study was to investigate HLA-G expression in colorectal cancer tumors and determine HLA-G expression relation between clinicopathological characteristics and survival time.

Methods: HLA-G expression was evaluated by immunohistochemistry (IHC) using anti-HLA-G antibody in 100 primary tumors of colorectal cancer with different stages.

Results: Our results showed that $25 \%$ of the colorectal cancer tissues had positive HLA-G expression and $75 \%$ no stained with antiHLA-G antibody. The HLA-G expression in advanced stages (III and IV) was more prevalent than those in earlier clinical stages (I and II) $(\mathrm{P}=0.0001)$. Results showed that HLA-G expression can serve as an independent factor for overall survival(OS). In this study, patients with HLA-G expression had significantly shorter survival time than those with negative expressions $(\mathrm{P}=0.023)$.

Conclusions: HLA-G expression can serve as an independent factor for OS and its expression may be directly related to aggressive tumor behavior via escape from the host antitumor immune defense. Protein expression of HLA-G correlates with poor prognosis in colorectal cancer.
\end{abstract}

Keywords: HLA-G expression, Prognostic Value, Colorectal Cancer

\section{Introduction}

Colorectal cancer is the fourth common cancer in men after stomach, bladder, and prostate cancer and second one among women after breast cancer $(1,2)$.

During the process of tumor development in colorectal cancer, evasion of immune surveillance and suppression of the immune system are two important traits of cancer cells $(3,4)$. These two pathways include a: down regulation of HLA class I expression, and b: ability of tumor cells to regulate the expression of non-classical HLA class I molecules (HLA-E and HLA-G) (5).

HLA-G is a non-classical major histocompatibility complex (MHC) class Ib antigen (6) whose physiologic expression is limited to extra villous trophoblastic cells, thymic epithelial cells, pancreatic islets, and erythroblasts (7-9). However, tumor cells can express HLA-G on the cell surface $(10,11)$.

HLA-G induces tolerance by binding to inhibitory receptors, such as the immunoglobulin-like transcript (ILT) receptor 2 present on lymphoid and myelomonocytic cells (12) and ILT-4 expresses by dendritic cell, macrophages, and monocytes $(13,14)$. In addition, natural killer (NK) cells represent an HLA-G-specific receptor named killer cell immunoglobulin-like receptor (KIR) (15). HLA-G directly interacts with different immune cell subpopulations and induces the maintenance of tolerance at different stages of the immune response. Therefore, further tumor cell escape from immune surveillance will occur (6).

Several studies have examined HLA-G expression in colorectal cancer with conflicting results in researches. It has been reported that expression of HLA-G is correlated with escape from immune surveillance during colon cancer development (16). Patients with positive HLA-G tumors had a significantly shorter survival time than patients with negative HLA-G tumors (17). Another study has reported there was no significant relation between clinicopathological characteristics and tumor HLA-G expression (18). Kawin et al. examined HLA-G by immunohistochemistry and reverse transcriptase polymerase chain reaction (RT-PCR), but they did not detect HLA-G expression in either mRNA or protein levels (19). Nevertheless, more studies are definitely needed to demonstrate the role of HLA-G in suppression of the immune system and maybe these findings con- 
tribute to the development of new cancer immunotherapy. The aim of this study is to evaluate the association of HLA$\mathrm{G}$ expression with clinicpathological parameters and survival time in Iranian colorectal cancer populations.

\section{Methods}

\subsection{Patients and Tissue Samples}

Our historical cohort study was approved by the ethics committee of the Research institute for gastroenterology and liver diseases (RIGLD), Shahid Beheshti University of Medical Sciences, Tehran, Iran, and all participating patients provided written informed consent for their information to be stored in the databases of RIGLD and to be used for research. The study population consisted of 100 colorectal cancer patients, of which paraffin-embedded tumor tissue was available. All patients had been diagnosed and treated with surgery between 1995 and 2016 in the RIGLD. The clinicopathological factors were determined according to the classification of malignant tumors as set out by the international union against tumor node- metastasis (TNM).

Tumor and clinicopathological data were retrieved from the patients' medical files and pathology reports; in addition, the survival time of these patients was confirmed until May 2016 using telephone inquiries.

\subsection{Immunohistochemical Staining}

We detected the expression level of HLA-G by immunohistochemistry (IHC) in examining tumor. A mouse monoclonal anti-HLA G antibody (ab52455 clone 4h84: AbCam, $\mathrm{UK}$ ); $4 \mathrm{H} 84 \mathrm{mAb}$ (specific for a peptide located in the $\alpha 1$ extracellular domain common to all HLA-G isoforms) was used in IHC staining. IHC for HLA-G tumor expression was performed on $4 \mu \mathrm{m}$-thick sections, which were cut from each receiver block and mounted on polylysine coated slides. The slides were deparaffinized 3 times in 100\% xylene, 5 minutes each, and rehydrated in a graded series of ethanol from $100 \%$ to $70 \%$. Endogenous peroxidase activity was blocked for 20 minutes in $0.3 \%$ hydrogen peroxide solution containing methanol at room temperature. For antigen retrieval, slides were boiled in Tris-EDTA Buffer (pH 9.0) for 15 minutes at maximum power $\left(100^{\circ} \mathrm{C}\right)$ in a microwave oven. Next, anti-HLA-G monoclonal antibody (1:100) was incubated for 1.5 hours, after which a thorough washing in a $0.01 \mathrm{M}$ phosphate-buffered saline (PBS) solution was performed. Binding sites of the primary antibody were visualized using a Dako Envision anti-mouse (K4001; DAKO Cytomation, Glostrup, Denmark) that was incubated for $1 \mathrm{~h}$ at room temperature. Subsequently, sections were visualized using 3, 3-diaminobenzidine solution (DAB). Tissue sections were counterstained with haematoxylin, dehydrated and finally mounted with glycerol gelatin.

The pathological features of all specimens and HLA$G$ expression results were confirmed by two pathologists from the department of pathology, gastroen-terology and liver diseases research center. IHC staining resulted in a visualization of the HLA-G as a brown-stained product. As shown in Figure 1, representative images of HLA$\mathrm{G}$ immunohistochemical for cytotrophoblast from firsttrimester human placenta served as a positive control (Figure $1 \mathrm{~A}$ ). For negative control, placenta which underwent the whole IHC staining without primary antibody was served (Figure 1B). Normal colorectal tissue was not stained with HLA-G but colorectal cancer tissue was stained with anti-HLA-G antibody (Figure 1C and 1D, respectively).

\subsection{Statistical Analysis Result}

Statistical analysis was performed using the SPSS software, version 16.0.0 (SPSS Inc., Chicago, IL). Depending upon the nature of the data, Pearson's chi-square test, Fisher's exact test, or the Mann- Whitney U test were used to compare variables.

Associations between tumor expressions of HLA-G and various clinicopathological variables, such as age, gender, tumor stage, and tumor differentiation (well, moderate and poor), were analyzed using the chi-square test. To evaluate the effect of the above-mentioned variables on survival univariate and multivariate, regression analyses were done using the Cox proportional hazard regression model, and Kaplan-Meier (log-rank test) curves were plotted. The significance of all statistics were recorded if $\mathrm{P}<0.05$.

\section{Results}

The analysis of HLA-G expression was performed on 100 colorectal cancer patients with stages I-IV. Clinicopathological features of patients are shown in Table 1. Of 100 samples analyzed, 59 were from male and 41 were from female subjects $49 \%$ of whom were under 62 years old. The mean age at the time of diagnosis was 50.52 years (SEM $=1.543$ years). 51 patients had a primary tumor of the colon and 49 patients had primary tumor of the rectosigmoid. Of the 100 colorectal rectal cancer patients, $20 \%$ were diagnosed with metastases to other organs.

\subsection{HLA-G Expression in Primary Colorectal Cancer}

To find out the role of HLA-G expression in colorectal cancer, we investigated the correlation of HLA-G expression with the demographic and clinicopathological parameters such as age, gender, TNM stage, tumor differen- 

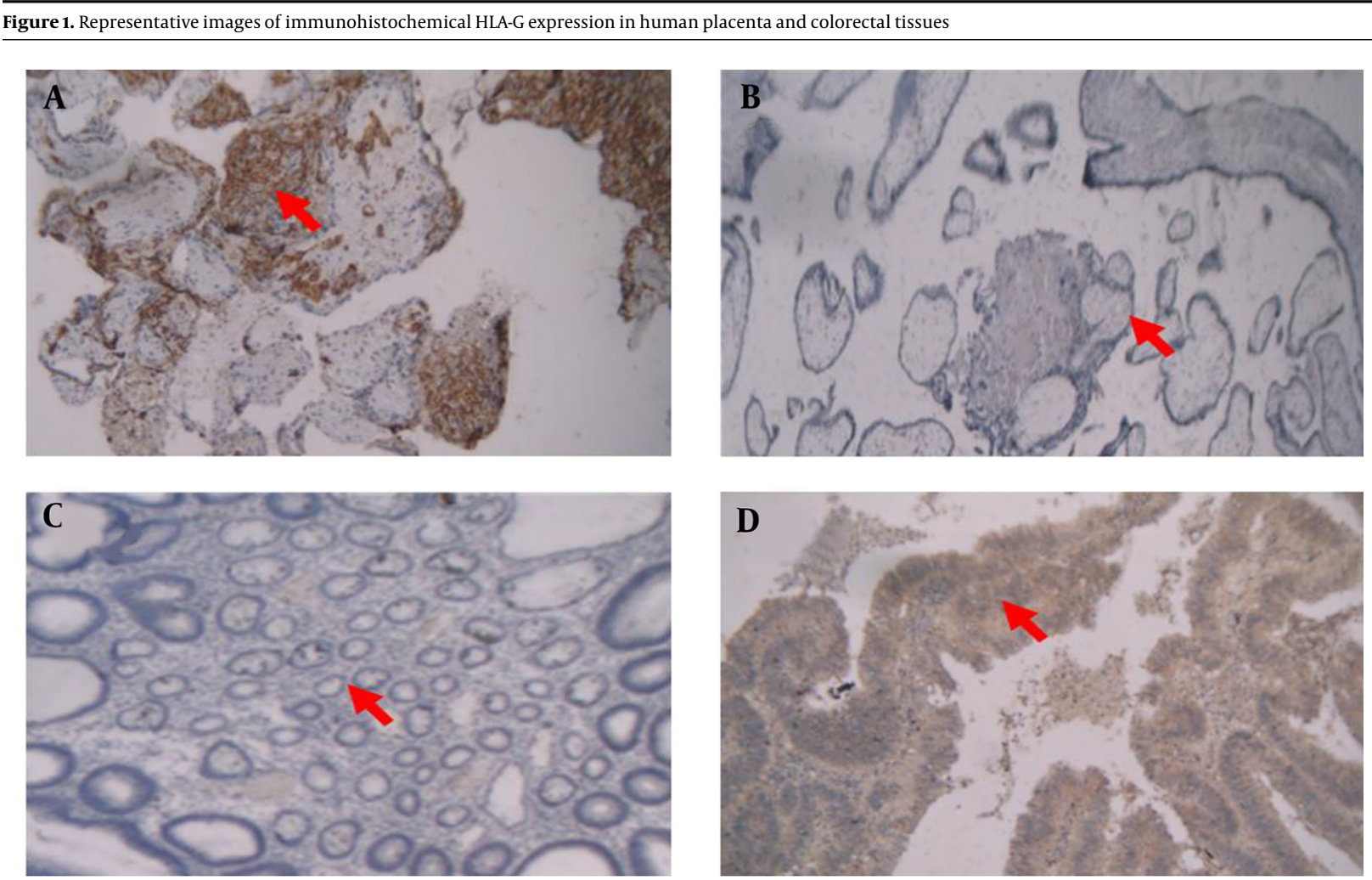

A, positive HLA-G staining in human placenta tissues; B, negative HLA-G staining in human placenta tissues; C, negative HLA-G staining in normal colorectal; D, positive HLA-G staining in colorectal cancer tissue.

tiation, tumor location, family history, vital status, and microsatellite instability (MSI) status (Table 2).

HLA-G expression was seen in 25 patients out of 100 patients (25\%) and the majority of the cases (75\%) were not stained with HLA-G antibody. We also found that positive staining for HLA-G in the primary tumor in men was higher than women (28.8\% vs $19.5 \%$ ) that was not statically significant. Tumors with positive HLA-G expression in the colon were comparable with those of the rectosigmoid. Considering tumor stage and HLA-G expression, Pearson chisquare test showed that HLA-G expression in stages III and VI (72\%) was significantly higher than those in the stages I and II $(28 \%)(\mathrm{P}<0.0001)$. We found no significant differences between positive and negative HLA-G expression regarding gender, age, differentiation, metastasis, and MSI status.

\subsection{Correlation of HLA-G Expression with Overall Survival}

All the characteristics with prognostic value in overall survival (age, gender, tumor stage, MSI status, tumor differentiation, family history and HLA-G expression) were inserted in Cox model (univariate and multivariate analyses). We did not find any significant correlation between overall survival and these prognostic factors, except for HLA-G expression.

Univariate and multivariate analyses showed that tumors with HLA-G expression have poor prognosis compared with tumors without HLA-G expression (Table 3 ).

Overall survival curves relative to HLA-G expression presented in Figure 2. Patients whose tumors showed loss of HLA-G had significantly a better overall survival (OS) (P $=0.023$ ) compared to patients with tumors with positive HLA-G expression.

\section{Discussion}

HLA-G plays an important role in prevention of miscarriage because of its fetoprotective effects by suppression of the maternal immune system (7). However, it has been reported that HLA-G expression in cancer cells lead to escape from the host's immune system (20). As shown in Table 4, the published data on HLA-G expression in different types of cancers had conflicts as follows: the positive rate of $90.9 \%$ positivity in esophageal squamous cell carcinoma (21) and $62.8 \%$ in cervical cancer (22), 60\% and 38.88\% in 
Table 1. Clinicopathologic Characteristics of Total Patients

\begin{tabular}{|c|c|}
\hline & No. (\%) \\
\hline \multicolumn{2}{|l|}{ Age, $y$} \\
\hline$<60$ & $49(49)$ \\
\hline$>60$ & $51(51)$ \\
\hline \multicolumn{2}{|l|}{ Gender } \\
\hline Male & $59(59)$ \\
\hline Female & $41(41)$ \\
\hline \multicolumn{2}{|l|}{ Tumor stage } \\
\hline I & $14(14)$ \\
\hline II & $45(45)$ \\
\hline III & $37(37)$ \\
\hline IV & $4(4)$ \\
\hline \multicolumn{2}{|l|}{ Differentiation } \\
\hline Well & $56(56)$ \\
\hline Moderate- Poor & $44(44)$ \\
\hline \multicolumn{2}{|l|}{ Location } \\
\hline Colon & $51(51)$ \\
\hline Rectusigmoid & $49(49)$ \\
\hline \multicolumn{2}{|l|}{ Metastasis } \\
\hline Yes & $20(20)$ \\
\hline No & $80(80)$ \\
\hline \multicolumn{2}{|l|}{ Family history } \\
\hline Yes & $43(43)$ \\
\hline No & $57(57)$ \\
\hline \multicolumn{2}{|l|}{ MSI status } \\
\hline MSH & $10(10)$ \\
\hline MSL & $10(10)$ \\
\hline MSS & $80(80)$ \\
\hline \multicolumn{2}{|l|}{ Vital status } \\
\hline Live & $74(74)$ \\
\hline Dead & $26(26)$ \\
\hline
\end{tabular}

breast cancer $(23,24)$ and different frequency of HLA-G expression in colorectal cancer.

Based on our results, HLA-G determined by immunohistochemistry was not expressed in normal colorectal tissues. However, $25 \%$ of the 100 colorectal cancer patients had positive HLA-G expression, which is consistent with Zeestraten et al. data in which they reported 20.3\% HLA-G expression (18). In line with results of Ye et al. we detected that expression of HLA-G significantly increased as the clinical stage advanced and patients in III-IV stages had sig-

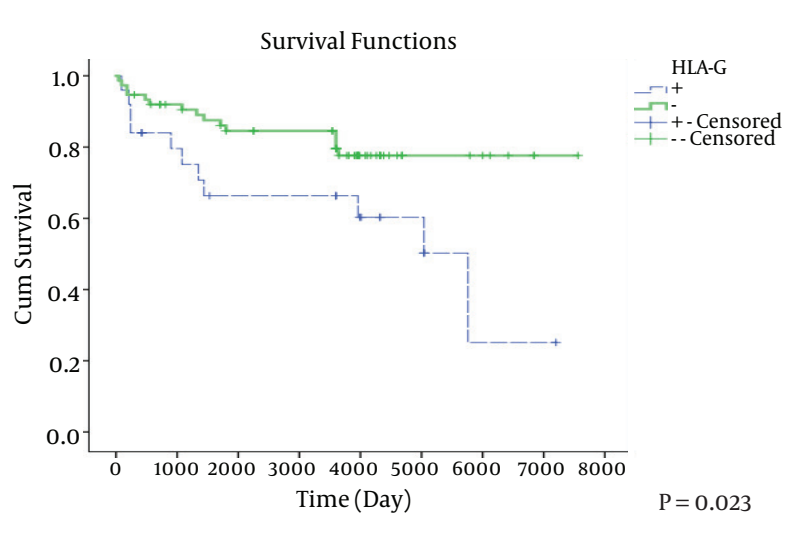

Figure 2. Overall Survival Curves Relative to HLA-G Status for All Colorectal Cancer Patients $(\mathrm{N}=100)$

nificantly higher HLA-G positivity than patients with early stages (17), but Zeestraten et al. have reported that HLA$\mathrm{G}$ expression in colorectal cancer patients was not correlated with clinicopathological characteristics (18). However, we did not find a statically significant correlation between HLA-G expression, and age, gender, tumor differentiation, familial history, metastasis, location of tumor and MSI status (Table 2).

Furthermore, in our study univariate and multivariate analyses showed that tumors with HLA-G expression had a poor prognosis compared to tumors with negative expression. These results correlate with Ye and Guo reports (17, 25). Zeestraten et al. have reported that HLA-G expression was not related to OS and DFS (18) contrary to this study. We found that patients with positive HLA-G expression displayed relevance to shorter overall survival despite low frequency of expression (25\%) compared with negative HLA-G expression using Kaplan-Meier analysis that is consistent with other studies $(17,25)$.

\subsection{Conclusions}

Our results demonstrate that patients with advanced stage had higher HLA-G expression and shorter survival than those with negative expression and HLA-G can be used as an independent prognostic factor. All these findings support the important role of HLA-G in immune surveillance of colorectal tumor cell that leads to escaping from the immune system. Considering Table 4 , it can be gathered that HLA-G expression in colorectal cancer had controversial results. Therefore, to HLA-G protein expression evaluation is suggested by anti-HLA-G antibodies such as a potentially useful prognostic indicator. Moreover, in cancer with overexpression of HLA-G, more studies are needed to design strategies for inhibiting HLA-G expression in cancer 
Table 2. Correlation Between the HLA-G Expression and Well-Established Prognosis Factors in Colorectal Cancer Patients ${ }^{\mathrm{a}}$

\begin{tabular}{|c|c|c|c|c|}
\hline \multirow[b]{2}{*}{ Variables } & \multicolumn{4}{|c|}{ HLA-G } \\
\hline & Total & No expression & Expression & $\chi^{2}$-P Value \\
\hline Age, $y$ & & & & 0.419 \\
\hline$\leq 60$ & $49(49)$ & $35(71.4)$ & $14(28.6)$ & \\
\hline$>60$ & $51(51)$ & $40(78.4)$ & $11(21.6)$ & \\
\hline Gender & & & & 0.291 \\
\hline Male & $59(59)$ & $42(71.2)$ & $17(28.8)$ & \\
\hline Female & $41(41)$ & $33(80.5)$ & $8(19.5)$ & \\
\hline TNM stage & & & & 0.0001 \\
\hline I, II & $59(59)$ & $52(88.1)$ & $7(11.9)$ & \\
\hline III, IV & $41(41)$ & $23(56.1)$ & $18(43.9)$ & \\
\hline Differentiation & & & & 0.352 \\
\hline Well & $56(56)$ & $44(78.6)$ & $12(21.4)$ & \\
\hline Moderate-Poor & $44(44)$ & $31(70.5)$ & $13(29.5)$ & \\
\hline Location & & & & 0.083 \\
\hline Colon & $51(51)$ & $42(82.4)$ & $9(17.6)$ & \\
\hline Rectusigmoid & $49(49)$ & $33(67.3)$ & $16(32.7)$ & \\
\hline Metastasis & & & & 0.564 \\
\hline Yes & $20(20)$ & $14(70)$ & $6(30)$ & \\
\hline No & $80(80)$ & $61(76.2)$ & $19(23.8)$ & \\
\hline Family history & & & & 0.56 \\
\hline Yes & $43(43)$ & $31(72.1)$ & $12(27.9)$ & \\
\hline No & $57(57)$ & $44(77.2)$ & $13(22.8)$ & \\
\hline MSI status & & & & 0.70 \\
\hline MSH & $10(10)$ & $8(80)$ & $2(20)$ & \\
\hline MSS/MSL & $90(90)$ & $67(74.4)$ & $23(25.6)$ & \\
\hline Vital status & & & & 0.018 \\
\hline Live & $74(74)$ & $60(81.1)$ & $14(18.9)$ & \\
\hline Dead & $26(26)$ & $15(57.7)$ & $11(42.3)$ & \\
\hline
\end{tabular}

Abbreviations: MSH, MSI-High; MSI, microsatellite instability; MSL, MSI-Low; MSS, microsatellite stable; TNM stage, tumor node- metastasis.

${ }^{\mathrm{a}}$ Values are expressed as No. (\%).

immunotherapies that can be combined or not with other treatments.

\section{Acknowledgments}

The proposal for this study was approved by the ethics committee of Shahid Beheshti University of Medical Sciences, Tehran, Iran. This study was supported by grant number 400/117 from the Shahid Beheshti University of Medical Sciences.

\section{Footnotes}

Authors' Contribution: Non declared.

Funding/Support: Non declared.

Conflict of Interest: The authors declare no conflict of interest.

\section{References}

1. Mahmodlou R, Mohammadi P, Sepehrvand N. Colorectal cancer in northwestern Iran. ISRN gastroenterol. 2012;2012. 
2. Hajmanoochehri F, Asefzadeh S, Kazemifar AM, Ebtehaj M. Clinicopathological features of colon adenocarcinoma in Qazvin, Iran: a 16 year study. Asian Pac J Cancer Prev. 2014;15(2):951-5. [PubMed: 24568524].

3. Parcesepe P, Giordano G, Laudanna C, Febbraro A, Pancione M. CancerAssociated Immune Resistance and Evasion of Immune Surveillance in Colorectal Cancer. Gastroenterol Res Pract. 2016;2016:6261721. doi: 10.1155/2016/6261721. [PubMed: 27006653].

4. Rouas-Freiss N, Moreau P, Menier C, Carosella ED. HLA-G in cancer: a way to turn off the immune system. Semin Cancer Biol. 2003;13(5):32536. [PubMed: 14708712].

5. Cavallo F, De Giovanni C, Nanni P, Forni G, Lollini PL. 2011: the immune hallmarks of cancer. Cancer Immunol Immunother. 2011;60(3):319-26. doi: 10.1007/s00262-010-0968-0. [PubMed: 21267721].

6. Amiot L, Ferrone S, Grosse-Wilde H, Seliger B. Biology of HLA-G in cancer: a candidate molecule for therapeutic intervention?. Cell Mol Life Sci. 2011;68(3):417-31. doi: 10.1007/s00018-010-0583-4. [PubMed: 21063893].

7. Papamitsou T, Toskas A, Papadopoulou K, Sioga A, Lakis S, Chatzistamatiou $\mathrm{M}$, et al. Immunohistochemical study of immunological markers: HLAG, CD16, CD25, CD56 and CD68 in placenta tissues in recurrent pregnancy loss. Histol Histopathol. 2014;29(8):1047-55. doi: 10.14670/HH-29.1047. [PubMed: 24557735].

8. Lefebvre S, Adrian F, Moreau P, Gourand L, Dausset J, Berrih-Aknin $S$, et al. Modulation of HLA-G expression in human thymic and amniotic epithelial cells. Hum Immunol. 2000;61(11):1095-101. [PubMed: 11137212].

9. Cirulli V, Zalatan J, McMaster M, Prinsen R, Salomon DR, Ricordi $\mathrm{C}$, et al. The class I HLA repertoire of pancreatic islets comprises the nonclassical class Ib antigen HLA-G. Diabetes. 2006;55(5):1214-22. [PubMed: 16644675].

10. Ibrahim EC, Guerra N, Lacombe MJ, Angevin E, Chouaib S, Carosella $E D$, et al. Tumor-specific up-regulation of the nonclassical class I HLA-G antigen expression in renal carcinoma. Cancer Res. 2001;61(18):6838-45. [PubMed: 11559559].

11. Urosevic M, Kurrer MO, Kamarashev J, Mueller B, Weder W, Burg G, et al. Human leukocyte antigen $\mathrm{G}$ up-regulation in lung cancer associates with high-grade histology, human leukocyte antigen class I loss and interleukin-10 production. Am J Pathol. 2001;159(3):817-24. doi: 10.1016/So002-9440(10)61756-7. [PubMed: 11549573].

12. Zhang Y, Lu N, Xue Y, Zhang M, Li Y, Si Y, et al. Expression of immunoglobulin-like transcript (ILT)2 and ILT3 in human gastric cancer and its clinical significance. Mol Med Rep. 2012;5(4):910-6. doi: 10.3892/mmr.2012.744. [PubMed: 22246571].

13. LeMaoult J, Zafaranloo K, Le Danff C, Carosella ED. HLA-G up-regulates ILT2, ILT3, ILT4, and KIR2DL4 in antigen presenting cells, NK cells, and T cells. FASEB J. 2005;19(6):662-4. doi: 10.1096/fj.04-1617fje. [PubMed: 15670976].

14. Zilberman S, Schenowitz C, Agaugue S, Benoit F, Riteau B, Rouzier R, et al. HLA-G1 and HLA-G5 active dimers are present in malignant cells and effusions: the influence of the tumor microenvironment. Eur J Immunol. 2012;42(6):1599-608. doi: 10.1002/eji.201141761. [PubMed: 22678912].

15. O'Callaghan CA, Bell JI. Structure and function of the human MHC class Ib molecules HLA-E, HLA-F and HLA-G. Immunol Rev. 1998;163:12938. [PubMed: 9700506].

16. Fukushima Y, Oshika Y, Nakamura M, Tokunaga T, Hatanaka H, Abe
Y, et al. Increased expression of human histocompatibility leukocyte antigen-G in colorectal cancer cells. Int J Mol Med. 1998;2(3):349-51. [PubMed: 9855710].

17. Ye SR, Yang H, Li K, Dong DD, Lin XM, Yie SM. Human leukocyte antigen $\mathrm{G}$ expression: as a significant prognostic indicator for patients with colorectal cancer. Mod Pathol. 2007;20(3):375-83. doi: 10.1038/modpathol.3800751. [PubMed: 17277760].

18. Zeestraten EC, Reimers MS, Saadatmand S, Goossens-Beumer II Dekker JW, Liefers GJ, et al. Combined analysis of HLA class I, HLAE and HLA-G predicts prognosis in colon cancer patients. Br J Cancer 2014;110(2):459-68. doi: 10.1038/bjc.2013.696. [PubMed: 24196788].

19. Leelawat K, Engprasert S, Pongchai-rerk U, Tuchinda S, Suthipintawong C, Leardkamolkarn V. No expression of human leukocyte antigen G (HLA-G) in colorectal cancer cells. I Med Assoc Thai. 2004;87(7):816-8. [PubMed: 15521238].

20. Barbara S, Simon JB. In: Resistance of Cancer Cells to CTL-Mediated Immunotherapy. Bonavida $\mathrm{B}$, Chouaib $\mathrm{S}$, editors. Los Angeles: Springer; 2015. Role of the Non-classical HLA Class I Antigens for Immune Escape.

21. Yie SM, Yang H, Ye SR, Li K, Dong DD, Lin XM. Expression of HLA-G is associated with prognosis in esophageal squamous cell carcinoma. Am J Clin Pathol. 2007;128(6):1002-9. doi: 10.1309/JNCW1QLDFB6AM9WE. [PubMed: 18024326].

22. Li XJ, Zhang X, Lin A, Ruan YY, Yan WH. Human leukocyte antigenG (HLA-G) expression in cervical cancer lesions is associated with disease progression. Hum Immunol. 2012;73(9):946-9. doi 10.1016/j.humimm.2012.07.041. [PubMed: 22820627].

23. Lefebvre S, Antoine M, Uzan S, McMaster M, Dausset J, Carosella ED, et al. Specific activation of the non-classical class I histocompatibility HLA-G antigen and expression of the ILT2 inhibitory receptor in human breast cancer. J Pathol. 2002;196(3):266-74. doi: 10.1002/path.1039. [PubMed: 11857488].

24. de Kruijf EM, Sajet A, van Nes JG, Natanov R, Putter H, Smit VT, et al. HLA-E and HLA-G expression in classical HLA class I-negative tumors is of prognostic value for clinical outcome of early breast cancer patients. J Immunol. 2010;185(12):7452-9. doi: 10.4049/jimmunol.1002629. [PubMed: 21057081].

25. Guo ZY, Lv YG, Wang L, Shi SJ, Yang F, Zheng GX, et al. Predictive value of HLA-G and HLA-E in the prognosis of colorectal cancer patients. Cell Immunol. 2015;293(1):10-6. doi: 10.1016/j.cellimm.2014.10.003. [PubMed: 25461612].

26. Swets M, Konig MH, Zaalberg A, Dekker-Ensink NG, Gelderblom $\mathrm{H}$, van de Velde CJ, et al. HLA-G and classical HLA class I expression in primary colorectal cancer and associated liver metastases. Hum Immunol. 2016;77(9):773-9. doi: 10.1016/j.humimm.2016.03.001. [PubMed: 26968946].

27. Barrier BF, Kendall BS, Sharpe-Timms KL, Kost ER. Characterization of human leukocyte antigen-G (HLA-G) expression in endometrial adenocarcinoma. Gynecol Oncol. 2006;103(1):25-30. doi: 10.1016/j.ygyno.2006.01.045. [PubMed:16530254].

28. Ishigami S, Natsugoe S, Miyazono F, Nakajo A, Tokuda K, Matsumoto M, et al. HLA-G expression in gastric cancer. Anticancer Res. 2006;26(3B):2467-72. [PubMed: 16821634].

29. Yie SM, Yang H, Ye SR, Li K, Dong DD, Lin XM. Expression of human leukocyte antigen $\mathrm{G}$ (HLA-G) correlates with poor prognosis in gastric carcinoma. Ann Surg Oncol. 2007;14(10):2721-9. doi: 10.1245/s10434007-9464-y. [PubMed: 17564748]. 
Table 3. Univariate and Multivariate Cox Regression Analyses of Possible Prognostic Variables and Parameters That Correlate with Overall Survival

\begin{tabular}{|c|c|c|c|c|c|}
\hline \multirow[t]{2}{*}{ Variables } & & \multicolumn{2}{|c|}{ Univariate Analysis } & \multicolumn{2}{|c|}{ Multivariate Analysis } \\
\hline & & Hazard Ratio for Death & PValue & Hazard Ratio for Death & $\chi^{2}$-P Value \\
\hline \multirow[t]{3}{*}{ Gender } & & & 0.643 & & 0.382 \\
\hline & Female & 1 ref. & & 1 ref. & \\
\hline & Male & $0.826(0.368-1.854)$ & & $0.671(0.274-1.642)$ & \\
\hline \multirow[t]{3}{*}{ Age } & & & 0.447 & & 0.425 \\
\hline & $\leq 60$ & 1 ref & & & \\
\hline & $>60$ & $1.349(0.624-2.919)$ & & $1.425(0.597-3.399)$ & \\
\hline \multirow[t]{3}{*}{ Location of tumor } & & & 0.173 & & 0.432 \\
\hline & Colon & 1 ref. & & 1 ref. & \\
\hline & Rectusigmoid & $0.581(0.266-1.269)$ & & $0.698(0.285-1.711)$ & \\
\hline \multirow[t]{3}{*}{ Differentiation } & & & 0.121 & & 0.078 \\
\hline & Poor-moderate & 1 ref. & & 1 ref. & \\
\hline & Well & $0.513(0.22-1.192)$ & & $0.443(0.179-1.094)$ & \\
\hline \multirow[t]{3}{*}{ TNM stage } & & & 0.729 & & 0.496 \\
\hline & & I, II & 1 ref. & 1 ref. & \\
\hline & III, IV & $0.827(0.403-1.887)$ & & $2.18(0.231-20.601)$ & \\
\hline \multirow[t]{3}{*}{ HLA-G expression } & & & 0.028 & & 0.045 \\
\hline & No & 1 ref. & & 1 ref. & \\
\hline & Yes & $1.551(1.049-2.295)$ & & $1.016(1.016-2.574)$ & \\
\hline \multirow[t]{3}{*}{ MSI status } & & & 0.218 & & 0.262 \\
\hline & MSH & 1 ref. & & 1 ref. & \\
\hline & MSS/MSL & $0.284(0.038-2.103)$ & & $0.299(0.036-2.463)$ & \\
\hline \multirow[t]{3}{*}{ Metastasis } & & & 0.306 & & 0.213 \\
\hline & No & 1 ref. & & 1 ref. & \\
\hline & Yes & $0.635(0.267-1.513)$ & & $0.533(0.199-1.433)$ & \\
\hline
\end{tabular}

Abbreviations: MSH, MSI-High; MSI, microsatellite instability; MSL, MSI-Low; MSS, microsatellite stable; TNM stage, tumor node- metastasis. 
Table 4. HLA-G Expression in Several Solid Tumors

\begin{tabular}{|c|c|c|c|c|}
\hline Type of Cancer & Method & HLA-G Protein Expression, \% & Results & Reference \\
\hline \multirow{2}{*}{ Colorectal cancer } & \multirow{2}{*}{$\mathrm{IHC}$} & \multirow{2}{*}{64.4} & $\begin{array}{l}\text { 1. HLA-G expression was } \\
\text { significantly correlated with } \\
\text { the clinicopathologic } \\
\text { characteristics. }\end{array}$ & \multirow{2}{*}{ (17) } \\
\hline & & & $\begin{array}{l}\text { 2. Patients with HLA-G } \\
\text { positive tumors had a } \\
\text { significantly shorter survival } \\
\text { time } 3 \text {. HLA-G expression can } \\
\text { serve as an independent } \\
\text { factor for OS. }\end{array}$ & \\
\hline Colorectal cancer/cell & RT-PCR IHC & 87.17 & $\begin{array}{l}\text { 1. The expression of HLA-G } \\
\text { mRNA was significantly more } \\
\text { frequent in colorectal cancer } \\
\text { than in the extraneoplastic } \\
\text { tissue. }\end{array}$ & $(16)$ \\
\hline \multirow{2}{*}{ Colorectal cancer } & \multirow{2}{*}{$\mathrm{IHC}$} & \multirow{2}{*}{29} & $\begin{array}{l}\text { 1. HLA-G expression in the } \\
\text { primary tumors was not } \\
\text { significantly correlated with } \\
\text { liver metastasis. }\end{array}$ & \multirow{2}{*}{ (26) } \\
\hline & & & $\begin{array}{l}\text { 2. Regarding HLA-G } \\
\text { expression no significant } \\
\text { difference between } \\
\text { synchronous or } \\
\text { metachronous onset of liver } \\
\text { metastasis was observed. }\end{array}$ & \\
\hline \multirow{2}{*}{ Colorectal cancer } & \multirow{2}{*}{ IHC } & \multirow{2}{*}{20.3} & $\begin{array}{l}\text { 1. HLA-G tumour expression } \\
\text { was not related to OS (Overall } \\
\text { Survival) and DFS } \\
\text { (disease-free survival). }\end{array}$ & \multirow{2}{*}{ (18) } \\
\hline & & & $\begin{array}{l}\text { 2. None of the } \\
\text { clinicopathological } \\
\text { characteristics were } \\
\text { significantly related to } \\
\text { tumour expression. }\end{array}$ & \\
\hline \multirow{2}{*}{ Colorectal cancer } & \multirow{2}{*}{ IHC } & \multirow{2}{*}{70.6} & $\begin{array}{l}\text { 1. Expression of HLA-G was } \\
\text { only significantly associated } \\
\text { with a pathological diagnosis. }\end{array}$ & \multirow{2}{*}{$(25)$} \\
\hline & & & $\begin{array}{l}\text { 2. Patients with HLA-G } \\
\text { expression had a significantly } \\
\text { poorer overall survival }\end{array}$ & \\
\hline $\begin{array}{l}\text { Endometrial } \\
\text { adenocarcinoma }\end{array}$ & IHC & 55 & $\begin{array}{l}\text { 1. The stage of cancer was } \\
\text { significantly correlated with } \\
\text { HLA-G staining }\end{array}$ & $(27)$ \\
\hline \multirow{2}{*}{ Breast cancer } & \multirow{2}{*}{$\mathrm{IHC}$} & \multirow{2}{*}{60} & $\begin{array}{l}\text { 1. Of the patients with no } \\
\text { tumor expression of HLA-G, } \\
56 \% \text { of patients were relapse } \\
\text { free after } 10 \mathrm{y} \text {. }\end{array}$ & \multirow{2}{*}{$(24)$} \\
\hline & & & $\begin{array}{l}\text { 2. Of the patients with tumor } \\
\text { expression of HLA-G, } 39 \% \text { of } \\
\text { patients were relapse free } \\
\text { after } 10 \mathrm{y} \text {. }\end{array}$ & \\
\hline
\end{tabular}




\begin{tabular}{|c|c|c|c|c|}
\hline \multirow{2}{*}{ Breast cancer } & IHC & \multirow{2}{*}{38.88} & $\begin{array}{l}\text { 1. HLA-G expression } \\
\text { significantly correlated with } \\
\text { inflammatory grade of breast } \\
\text { cancer lesions. }\end{array}$ & \multirow{2}{*}{ (23) } \\
\hline & PCR & & $\begin{array}{l}\text { 2. There was no significant } \\
\text { relationship between HLA-G } \\
\text { expression and tumor grade, } \\
\text { type, and patient age. }\end{array}$ & \\
\hline \multirow{3}{*}{ Gastric cancer } & \multirow{3}{*}{ IHC } & \multirow{3}{*}{45.21} & $\begin{array}{l}\text { 1. HLA-G expression decreased } \\
\text { as the clinical stage advanced. }\end{array}$ & \multirow{3}{*}{ (28) } \\
\hline & & & $\begin{array}{l}\text { 2. Survival rate in the } \\
\text { HLA-G-positive group was } \\
\text { significantly higher than } \\
\text { those with negative } \\
\text { expression. }\end{array}$ & \\
\hline & & & $\begin{array}{l}\text { 3. HLA-G expression may play } \\
\text { a role in the early clinical } \\
\text { stages by protecting cancer } \\
\text { cells from tumor infiltrating } \\
\text { effectors. }\end{array}$ & \\
\hline \multirow{3}{*}{ Gastric carcinoma } & \multirow{3}{*}{ IHC } & \multirow{3}{*}{71} & $\begin{array}{l}\text { 1. HLA-G expression in the } \\
\text { tumors was significantly } \\
\text { correlated with } \\
\text { clinicopathologic } \\
\text { characteristics. }\end{array}$ & \multirow{3}{*}{ (29) } \\
\hline & & & $\begin{array}{l}\text { 2. Survival rate in the } \\
\text { HLA-G-positive patients was } \\
\text { significantly shorter than } \\
\text { those with negative } \\
\text { expression. }\end{array}$ & \\
\hline & & & $\begin{array}{l}\text { 3. HLA-G was an independent } \\
\text { prognostic factor. }\end{array}$ & \\
\hline \multirow{3}{*}{$\begin{array}{l}\text { Esophageal squamous cell } \\
\text { carcinoma }\end{array}$} & \multirow{3}{*}{ IHC } & \multirow{3}{*}{90.9} & $\begin{array}{l}\text { 1.HLA-G expression was } \\
\text { significantly correlated with } \\
\text { clinicopathologic } \\
\text { characteristics }\end{array}$ & \multirow{3}{*}{ (21) } \\
\hline & & & $\begin{array}{l}\text { 2. Patients with positive } \\
\text { HLA-G expression had a } \\
\text { significantly worse prognosis. }\end{array}$ & \\
\hline & & & $\begin{array}{l}\text { 3. HLA-G expression was an } \\
\text { independent prognostic } \\
\text { factor. }\end{array}$ & \\
\hline \multirow{2}{*}{ Cervical cancer } & \multirow{2}{*}{$\mathrm{IHC}$} & \multirow{2}{*}{62.8} & $\begin{array}{l}\text { 1. HLA-G expression was } \\
\text { associated with the disease } \\
\text { progression in patients }\end{array}$ & \multirow{2}{*}{ (22) } \\
\hline & & & $\begin{array}{l}\text { 2. HLA-G expression in stages } \\
\text { III and IV was higher than } \\
\text { those of stages I and II. }\end{array}$ & \\
\hline
\end{tabular}

